\title{
KUNZITE FROM THE HAAPALUOMA PEGMATITE QUARRY, WESTERN FINLAND
}

\author{
SEPPO I. LAHTI and RISTO SAIKKONEN
}

LAHTI, SEPPO I. and SAIKKONEN, RISTO, 1986: Kunzite from the Haapaluoma pegmatite quarry, western Finland. Bull. Geol. Soc. Finland 58, Part 2, $47-52$.

A purple transparent crystal of spodumene, or kunzite, was encountered in the Haapaluoma feldspar quarry, western Finland. The crystal, which is about seven centimetres long, is embedded in purple, fine-scaled lepidolite. The kunzite has crystallized in a postmagmatic fracture filling of albite-quartz-spodumene-lepidolite-red tourmaline crossing the main pegmatite dyke.

Spodumene is a common mineral in certain pegmatites, but this is the first report of kunzite, a gem quality spodumene, in Finland.

The wet chemical analysis of the Haapaluoma kunzite shows (wt \%): $\mathrm{SiO}_{2} 63.85$, $\mathrm{TiO}_{2}$ 0.01, $\mathrm{Al}_{2} \mathrm{O}_{3}$ 27.72, $\mathrm{MnO} 0.16, \mathrm{Fe}_{2} \mathrm{O}_{3}$ tot. 0.16, $\mathrm{MgO} 0.05, \mathrm{ZnO} 0.01, \mathrm{Tl}_{2} \mathrm{O}$ 0.0, $\mathrm{CaO}$ 0.07, $\mathrm{BeO} 0.00, \mathrm{Na}_{2} \mathrm{O} 0.59, \mathrm{~K}_{2} \mathrm{O} 0.13, \mathrm{Li}_{2} \mathrm{O}$ 7.49, $\mathrm{Rb}_{2} \mathrm{O} 0.00, \mathrm{Cs}_{2} \mathrm{O} 0.00$, $\mathrm{P}_{2} \mathrm{O}_{5} 0.00, \mathrm{H}_{2} \mathrm{O}+0.08, \mathrm{H}_{2} \mathrm{O}-0.02$, total 100.34 . The trace elements determined with an optical emission spectrograph are as follows (ppm): Cr 510, Ga330, Sn 120, Sc 26, Ge 19, Sr $<30, \mathrm{Co}<20, \mathrm{Cu}<15, \mathrm{Ni}<15$ and $\mathrm{V}<15$. The unit cell formula computed on the basis of six oxygens $(\mathrm{Z}=4)$ is as follows: $\mathrm{Li}_{0.94} \mathrm{Na}_{0.04} \mathrm{Al}_{1.02} \mathrm{Si}_{1.99} \mathrm{O}_{6}$.

The mineral is strongly pleochroic with $\mathrm{X}=\mathrm{Y}=$ amethystine purple and $\mathrm{Z}=$ weak purplish or colourless. The optical properties are $\alpha=1.660, \beta=1.665$, $\gamma=1.679,+2 \mathrm{Vmeas} .=61^{\circ}$ and $+2 \mathrm{~V}$ calc. $=62^{\circ}$. The mineral shows weak pale orange fluorescence under long and short wave UV light. The measured specific gravity (3.19) is identical to the calculated density within the limits of measuring accuracy. The unit cell is monoclinic with the space group $\mathrm{C} 2 / \mathrm{c}$ and $\mathrm{a}=9.469 \AA$, $\mathrm{b}=8.399 \AA, \mathrm{c}=5.225 \AA, \beta=110.16^{\circ}$ and $\mathrm{V}=390.04 \AA^{3}$.

The composition of kunzite and a grey spodumene from the Na-stage assemblage of the same quarry are nearly identical. The content of iron and lithium is, however, lower in kunzite and the content of sodium is higher. The colour of the mineral may be due to the presence of relatively high concentrations of $\mathrm{Mn}^{3+}$ and a low $\mathrm{Fe} / \mathrm{Mn}$ ratio (1.0). The chemical composition and physical properties of the Haapaluoma kunzite resembles closely to those reported in the literature for similar spodumene varieties.

Key words: kunzite, physical properties, chemical composition, Haapaluoma, pegmatite.

Seppo I. Lahti and Risto Saikkonen: Geological Survey of Finland, Kivimiehentie 1, SF-02150 Espoo, Finland.

\section{Introduction}

While engaged on regional rock mapping, the first of the authors studied the minerals of the
Haapaluoma pegmatite quarry near Peräseinäjoki, western Finland, and encountered there a long crystal of purple, transparent spodumene, or kunzite. Spodumene has been reported from 
many pegmatite dykes, e.g. in southern and central Ostrobothnia (Haapala 1966), SomeroTammela (Aurola 1963), Eräjärvi (Lahti 1981) and Kitee-Tohmajärvi (Kallio and Alviola 1975), but this is the first observation of gem quality spodumene in Finland. The mineral was, therefore, studied in detail. The first of the authors (S.I.L.) is responsible for the mineralogical description and determinations of physical properties, and the second (R.S) for the chemical analysis of the mineral.

The Haapaluoma pegmatite consists of two parallel dykes trending east-west and intruding the granodioritic country rock. The geology and mineralogy of the dykes have been described by Haapala (1966), Haapala et al. (1967) and Lahti et al. (1981). The surrounding area has been mapped by Tyrväinen (1979) and Lahti (unpublished map sheet 2221 Jalasjärvi). The main minerals of the pegmatite are microcline, albitic plagioclase, quartz and muscovite with minor black tourmaline, garnet and fluorapatite. The dyke is a typical zoned lithium pegmatite characterized by intense postmagmatic albitization and crossing spodumene-quartz-lepidolite-albite fracture fillings that contain accessory beryl, cassiterite, fluorapatite, columbite, eucryptite and some other more rare pegmatite minerals.

The pegmatite has been quarried for feldspar by the Oy Lohja Ab and Paraisten Kalkki Oy companies. The large waste rock piles around the eastern main quarry have provided much material for mineralogical studies.

Spodumene occurs in the pegmatite as long flattened prisms. The crystals are usually 10-30 $\mathrm{cm}$ long, although some may reach $60 \mathrm{~cm}$. The colour is usually grey or greenish. The greenish varieties are partly or completely altered into clay minerals. The fresh varieties have a purplish tint. The crystals are not usually transparent, only a few having been encountered during mining that are partly both transparent and purple in colour. The kunzite crystal found by the first of the authors is exceptionally long and of gem quality. In addition to spodumene, some small trans- parent beryl and tourmaline crystals, that are partly transparent or translucent were encountered from the eastern main quarry. The gem quality beryl is pink (morganite) and the tourmaline red.

\section{Occurrence}

The kunzite crystal studied in detail was encountered in a pegmatite block consisting mainly of purplish gray spodumene, deep purple lepidolite, lithium tourmaline with platy albite and quartz. The mineral is embedded in massive fine grained lepidolite. The associated lithium tourmaline is red or sometimes green with a pink rim. The kunzite crystal (Fig. 1) was originally a flattened prism about seven centimetres long $(2-2.5 \mathrm{~cm}$ thick) with poorly developed crystal faces. Some parts of it show small inclusions of red or colourless tourmaline and lepidolite.

\section{Physical properties}

The Haapaluoma kunzite is transparent and amethystine purple in colour. It exhibits strong cleavage in two directions parallel to the prism faces ((010) and (110) faces) almost at right angles to each other. Although the crystal has many cracks, some parts are perfect and unbroken.

The mineral is strongly pleochroic with $\mathrm{X}=\mathrm{Y}=$ purple and $\mathrm{Z}=$ colourless or light purple. The pleochroism can be observed in thick plates or crystal fragments, but the mineral is colourless in thin sections. The measured optical properties of the kunzite compared with those given by Haapala (1966) for the normal grey $\mathrm{Na}$ stage spodumene are listed in Table 1 . The refractive indices were measured with the immersion method and the indices of the liquids were tested invariably with an Abbe refractometer. The optic axial angle was measured from a thin section on a universal stage. The Table shows, 
Fig. 1. The kunzite crystal (right) embedded in purple massive lepidolite.

The length of the crystal is $5 \mathrm{~cm}$.

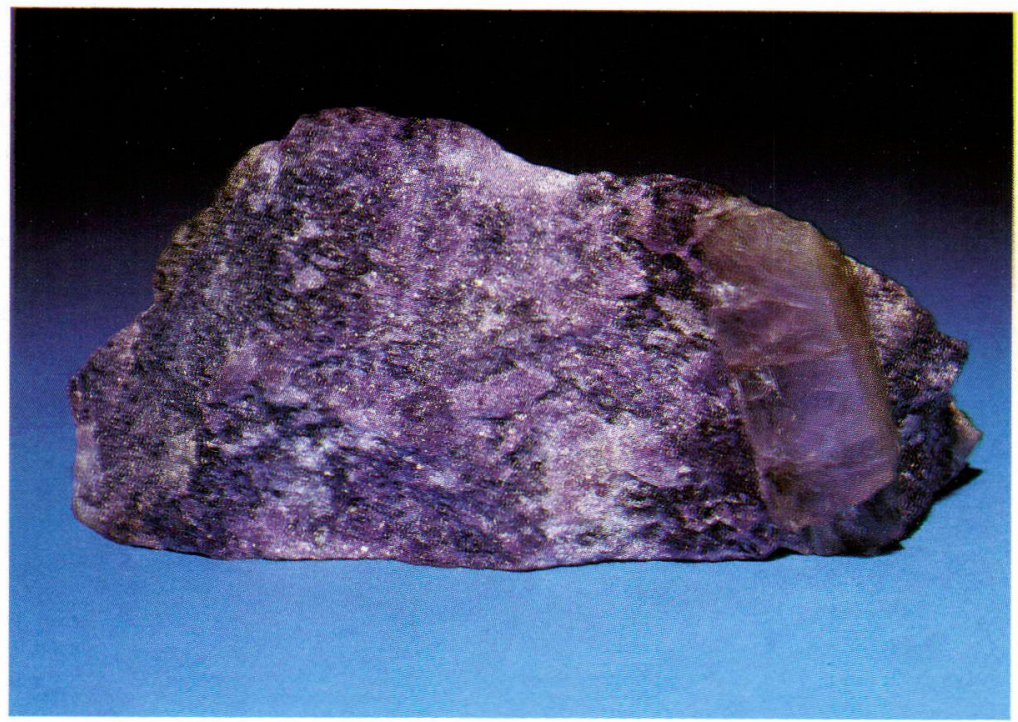

that the measured and calculated values are very close to each other.

The mineral shows weak, pale orange fluorescence in the long and short-wave ultra-violet light. The fluorescence of the purplish grey spodumene that is not transparent, is much stronger and the colour similar.

Table 1. Physical properties and unit cell dimensions of the Haapaluoma spodumene varieties.

\begin{tabular}{lllll}
\hline & \multicolumn{2}{c}{1} & \multicolumn{2}{c}{2} \\
\hline Unit cell: & & & & \\
a $(\AA)$ & & & \\
b $(\AA)$ & 9.469 & \pm 0.003 & 9.464 & \pm 0.003 \\
c $(\AA)$ & 8.399 & \pm 0.003 & 8.391 & \pm 0.003 \\
$\beta\left({ }^{\circ}\right)$ & 5.225 & \pm 0.003 & 5.220 & \pm 0.003 \\
V $\left(\AA^{3}\right)$ & 110.16 & \pm 0.08 & 110.17 & \pm 0.08 \\
Space group & 390.04 & & 389.12 & \\
Sp. gr. & $\mathrm{C} 2 / \mathrm{c}$ & & $\mathrm{C} 2 / \mathrm{c}$ & \\
D calc. (g/cm $\left.{ }^{3}\right)$ & 3.196 & & 3.155 & \pm 0.003 \\
Optical properties: & & & 3.19 & \\
& 1.660 & \pm 0.001 & 1.659 & \pm 0.001 \\
& 1.665 & \pm 0.001 & 1.664 & \pm 0.001 \\
& 1.679 & \pm 0.001 & 1.676 & \pm 0.001 \\
$\gamma-\alpha$ & 0.019 & & 0.017 & \\
$+2 \mathrm{~V}$ meas. $\left({ }^{\circ}\right)$ & $61 \pm 1$ & & $65 \pm 2$ & \\
$+2 \mathrm{~V}$ calc. $\left({ }^{\circ}\right)$ & 62.2 & & 66 & \\
\hline
\end{tabular}

1. Kunzite (this study).

2. Normal Na-stage grey spodumene (Haapala 1966).
The specific gravity of the kunzite was determined from three separate transparent grains with heavy liquids (dijodmethan) and an areometer. The specific gravity of the heaviest fragment given in Table 1 is very near the calculated density, whereas the specific gravity of the other fragments is considerably lower obviously because of the cracks observed in the mineral. Fluid inclusions were not found in the thin sections.

\section{X-ray studies}

The unit cell dimensions of the kunzite are given in Table 1 and the X-ray powder diffraction data in Table 2. In the tables the X-ray data are compared with those given by Haapala (1966) for the grey Na-stage spodumene from the same quarry.

The mineral were first studied in the precession camera. The a- and b-axis 0 - and 1-level precession photographs confirmed $\mathrm{C} 2 / \mathrm{c}(15)$ as the space group of the mineral. The $\mathrm{X}$-ray powder pattern was recorded using a Philips diffractometer scanning speed of $1 / 4$ degrees a minute and with silicon as an internal standard. The 
Table 2. X-ray powder diffraction data for kunzite from the Haapaluoma pegmatite quarry. Diffractometer, Ni-filtered $\mathrm{Cu}$ radiation $(\lambda \mathrm{CuK} \alpha 1.5418)$, silicon as standard, scanning speed $1 / 4^{\circ} / \mathrm{min}$.

\begin{tabular}{|c|c|c|c|}
\hline hkl & d meas. & d calc. & $\mathrm{I} / \mathrm{I}_{0}$ \\
\hline $110^{*}$ & 6.11 & 6.11 & 32 \\
\hline $200^{*}$ & 4.45 & 4.44 & 15 \\
\hline$\overline{1} 11$ & 4.360 & 4.361 & 13 \\
\hline $020^{*}$ & 4.200 & 4.199 & 61 \\
\hline $111^{*}$ & 3.446 & 3.446 & 18 \\
\hline 021 & 3.188 & 3.190 & 25 \\
\hline 220 & 3.051 & 3.052 & 6 \\
\hline$\overline{2} 21^{*}$ & 2.920 & 2.920 & 100 \\
\hline$\overline{3} 11 \mathrm{~b}$ & 2.859 & 2.860 & 12 \\
\hline $310^{*}$ & 2.794 & 2.794 & 93 \\
\hline 130 & 2.668 & 2.670 & 22 \\
\hline $002 b$ & 2.450 & 2.452 & 17 \\
\hline 221 & 2.353 & 2.354 & 15 \\
\hline$\overline{3} 31 \mathrm{~b}$ & 2.059 & 2.060 & 17 \\
\hline 330$\} \mathrm{b}$ & 2.031 & $2.035\}$ & 11 \\
\hline$\overline{4} 02\}^{\circ}$ & & $2.031\}$ & \\
\hline$\overline{2} 41$ & 1.865 & 1.865 & 28 \\
\hline$\overline{5} 31$ & 1.568 & 1.568 & 38 \\
\hline 350 & 1.461 & 1.461 & 33 \\
\hline 0601 & 1.399 & 1.400 & 8 \\
\hline 620$\}$ & & $1.397\}$ & \\
\hline 531 & 1.331 & 1.331 & 18 \\
\hline
\end{tabular}

b broad peak

* used in computing unit cell dimensions

powder data are based on two separate records. The measured and calculated values are in good accordance, although only six separate reflections were used when computing the unit cell dimensions.

\section{Chemical analysis}

Kunzite was first analysed with the aid of an optical emission spectrograph and then using wet chemical methods. The weight loss at $105^{\circ} \mathrm{C}$ $\left(\mathrm{H}_{2} \mathrm{O}-\right)$ was measured on a $0.5 \mathrm{~g}$ subsample. The portion was fused with $\mathrm{Na}_{2} \mathrm{CO}_{3}$, after which silica was determined gravimetrically by dehydration twice with hydrochloric acid. The residual silica retained in the filtrate was determined colorimetrically as the molybdenum blue complex. The $\mathrm{R}_{2} \mathrm{O}_{3}$ group was precipitated and aluminium was calculated by difference. Calcium and magnesium were determined by atomic absorption spectrophotometry (AAS).

One portion $(0.25 \mathrm{~g})$ was decomposed with hydrofluoric-perchloric-nitric acid, and aliquots of this solution were used for photometric determination of total iron by the $1.14-\mathrm{HCl}$ method, of titanium using Tiron, of manganese with potassium periodate, and of phosphorus as the yellow molybdovanadophosphoric acid complex. Lithium, sodium, potassium, rubidium, caesium, beryllium, zinc and thallium were analysed by AAS. $\mathrm{H}_{2} \mathrm{O}+$ was determined from a $0.35 \mathrm{~g}$ subsample by the Penfield method using lead oxide as a flux. Strontium, scandium, vanadium, chromium, cobalt, gallium, germanium, tin, nickel and copper were determined by optical emission spectroscopy.

Detailes of the accuracy and precision of the methods used in the wet chemical and emission spectrographic analyses at the Geological Survey and in the present work, too, are given by $\mathrm{Da}-$ nielsson and Saikkonen (1985).

The chemical analysis and the atomic composition of the mineral are compared with those given by Haapala (1966) for the grey spodumene from the same quarry given in Table 3 . The chemical formula of kunzite computed from the chemical analysis on the basis of six oxygens ( $\mathrm{Z}=4$, water is omitted as non-essential) $\mathrm{Li}_{0.94} \mathrm{Na}_{0.04} \mathrm{Al}_{1.02} \mathrm{Si}_{1.99} \mathrm{O}_{6}$ is very close to the ideal formula $\mathrm{LiAlSi}_{2} \mathrm{O}_{6}$.

\section{Discussion}

Kunzite and other coloured spodumene varieties are late-stage minerals in zoned lithium pegmatites that have a long and complex crystallization history. The mineral occurs in the middle parts of the dykes, usually in cavities embedded in clay minerals (Jahns and Wright 1951, Jahn 1974, Weber 1963 p. 84-86, Mills 1984). Associated minerals may include euhedral crystals of microcline, quartz, green and red tourmaline, beryl and topaz. 
Table 3. Chemical composition of the Haapaluoma spodumene varieties.

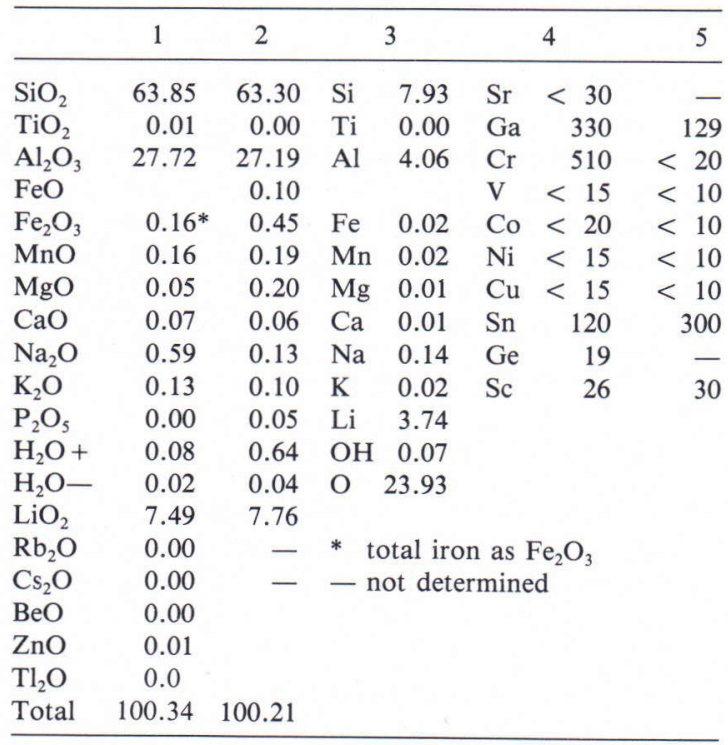

1. Wet chemical analysis (wt \%) of kunzite from the Li-stage assemblage.

2. Chemical composition of normal grey spodumene from the Na-stage assemblage (Haapala 1966).

3. Content of unit cell of kunzite on the basis of 24 oxygens.

4. Trace element composition of kunzite (ppm), spectrographic determinations of sample no. 1 by Ari Puisto.

5. Trace element composition of grey spodumene (ppm), spectrographic determinations of sample no. 2 by Raimo Lahtinen.

Kunzite has been regarded as one of the most beautiful and precious gem minerals since it was first discovered from Pala, California at the beginning of this century. The mineral has been reported from certain localities in the United States, Brasil, Madagascar and Afghanistan (Webster 1962, Dunn 1974, Bariand and Pollen 1978, Mills 1984). However, only limited data are available on the composition and physical properties of the mineral.

Iron and manganese are typical trace elements in kunzite and the colour of the mineral is associated with these elements (Claffy 1953, Leckebush et al. 1974, Deer et al. 1974). According to the chemical analyses presented in the literature, kunzite from Pala, California contains 0.073 wt $\% \mathrm{MnO}$ and 0.020 wt $\% \mathrm{Fe}_{2} \mathrm{O}_{3}$. According to Leckebush et al. (1974), the Afghanistan kunzites show 0.04-0.12 wt \% Mn and 0.07$0.12 \mathrm{wt} \% \mathrm{Fe}$. The content of iron in normal grey or pinkish spodumene, especially that from the homogeneous spodumene pegmatites is much higher, i.e. $0.1-0.8$ wt $\% \mathrm{Fe}_{2} \mathrm{O}_{3}$ (Gabriel 1942, Hassan and Labib 1978).

The purple or violet kunzite derive its colour from manganese. Spectroscopic determinations by Hassan and Labib (1978) (see also Cohen and Janezic 1983) indicate that the colour is connected with $\mathrm{Mn}^{+3}$. They suggest that natural radioactivity converts $\mathrm{Mn}^{+2}$ into $\mathrm{Mn}^{+3}$, and that the concentrations of manganese and/or the low $\mathrm{Fe} / \mathrm{Mn}$ ratio cause the darkening of the colour of the mineral (Claffy 1953, Leckebush et al. 1974, Mills 1984).

The kunzite in the Haapaluoma pegmatite is one of the late-stage minerals. In contrast to the other kunzite-bearing pegmatites, the dyke is totally devoid of gem mineral pockets. The associated minerals reveal that kunzite crystallized in the postmagmatic fracture fillings after the crystallization of the main dyke. Haapala (1966) divides the crystallization of fracture fillings and replacement bodies into two main stages: the $\mathrm{Na}$ stage and the later Li stage. Spodumene, lepidolite and red tourmaline are typical of the lithium stage assemblage. Kunzite crystallized in the fracture fillings as the last spodumene variety after red tourmaline, but before massive lepidolite.

The composition of the Haapaluoma kunzite does not differ significantly from that of the grey spodumene in the same quarry. The $\mathrm{Si} / \mathrm{Al}$ ratio of both varieties is near $2 / 1$. The content of iron and lithium are, however, lower in kunzite, and the content of sodium somewhat higher. The normal grey spodumene of the quarry contains 3.4 times more iron than kunzite and the $\mathrm{Fe} / \mathrm{Mn}$ ratio (2.4) is higher. The relatively low concentrations of iron and manganese, and the low $\mathrm{Fe} / \mathrm{Mn}$ ratio (1.0) of the Haapaluoma kunzite indicate that the analytical results are in agreement with the kunzite analyses reported in the literature. 
The optical properties and unit cell dimensions of the Haapaluoma kunzite do not differ significantly from those reported in the literature for similar spodumene varieties. The refractive indices of this kunzite are identical with those reported by Edgar (1968) for the kunzite from Pala, California, but differ somewhat from those given by Dunn (1974) for the Afghanistan gem spodumenes. The unit cell dimensions agree well with those reported by Haapala (1966) for the grey Nastage spodumene of the same quarry.

Acknowledgements. The authors are indebted to Jukka Keskinen for his help during the studies. Mirja Saarinen kindly recorded the X-ray diffractograms. Raimo Lahtinen and Ari Puisto carried out the spectrographic analyses of the mineral. Professor Ilmari Haapala and Mrs. Marjatta Virkkunen kindly read the manuscript and gave valuable suggestions. We express our cordial thanks to all the above persons for their help.

\section{References}

Aurola, Erkki, 1963. On the pegmatites in the Torro area, south-western Finland. Bull. Comm. Geol. Finlande 206. $32 \mathrm{p}$.

Bariand, Pierre \& Poullen, J. F., 1978. The pegmatites of Laghman, Nuristan, Afghanistan. Mineral. Rec. 9, $301-308$.

Cohen, Alvin J. \& Janezic, Gary G., 1983. The crystalfield spectra of the $3 \mathrm{~d}^{3}$ ions, $\mathrm{Cr}^{3+}$ and $\mathrm{Mn}^{4+}$ in green spodumenes. In The Significance of Trace Elements in Solving Petrogenetic Problems \& Controversies. Theophrastus Publications S.A., Athens, Greece. p. 899-904.

Claffy, E. W., 1953. Composition, tenesbrescence and luminescence of spodumene minerals. Amer. Mineral. 38, 919-931.

Danielsson, Ringa \& Saikkonen, Risto, 1985. Chemical analysis of USGS-W-2, USGS-DNC-1 and USGS-BIR-1 standard rocks. Geol. Surv. Finland, Rept. Inv. 70, 12 p.

Deer, W. A.; Howie, R. A. \& Zussman, J., 1978. Rock forming minerals. Vol. 2A Single-chain silicates. Longman Group limited, London. 668 p.

Dunn, Pete J., 1974. Gem spodumene and achroite tourmaline from Afghanistan. Journ. Gemm. 14, 170-174.

Edgar, A., D., 1968. The $\alpha-\beta \mathrm{LiAlSi}_{2} \mathrm{O}_{6}$ (spodumene) transition from 5000 to $45000 \mathrm{lb} / \mathrm{in} \mathrm{pH}_{2} \mathrm{O}$. Intern. Min. Assoc. Papers Prog. Fifth General Meeting, Cambridge, 1966, 222-231.

Gabriel, Alton; Slavin, Morris \& Carl, H. F., 1942. Minor constitutions in $\alpha$-spodumene. Econ. Geol. 37, 116-125.

Haapala, Ilmari, 1966. On the granitic pegmatites in the Peräseinäjoki-Alavus area, South Pohjanmaa, Finland. Bull. Comm. Geol. Finlande 224. 98 p.

-; Siivola, Jaakko \& Löfgren, Arvo, 1967. On the Haapaluoma scandium-bearing columbite and its inclusions. Bull. Comm. Geol. Finlande 229, 95-100.

Hassan, Farkhonda \& Labib, Maher, 1978. Induced color centers in $\alpha$-spodumene called kunzite. N. Jb. Miner. Abh. 134, 104-115.
Jahns, Richard H., 1974. Tourmaline-bearing pockets in pegmatite of the Pala district, San Diego County, California. 70th annual meeting, Geol. Soc. America, Abstracts with programs, vol. 6, 3, 197-198.

— \& Wright Lauren A., 1951. Gem- and lithium-bearing pegmatites of the Pala district, San Diego County, California. State of California, Department of Natural Resources. Calif. Div. Mines, Special Report 7-A 72 p.

Kallio, Pekka \& Alviola, Reijo, 1975. Triphylites and lithiophilites from the granite pegmatites of the communes of Kitee and Tohmajärvi, E. Finland. Fortsch. Mineral. 52, spec. issue: IMA-papers 9th meeting, 279-283.

Lahti, Seppo, 1981. On the granitic pegmatites of the Eräjärvi area in Orivesi, southern Finland. Geol. Surv. Finland, Bulletin 314. 82 p.

-; Kallio, Pekka \& von Knorring, Oleg, 1982. The composition, physical properties and occurrence of eucryptite from the Haapaluoma pegmatite. Bull. Geol. Soc. Finland 54, 1-2. 5-13.

Leckebusch, Rudolf; Recker, Kurt \& Triche, Claude, 1974. Relation entre couleur et luminescence des spodumenes d'Afghanistan et teneurs en chrome, manganese et fer. C.R. Sc. Paris. 1541-1544.

Mills, Meredith Workman, 1984. Kunzite. Lapidary Journal 38, 546-561.

Tyrväinen, Aimo, 1970. Kallioperäkartta (Pre quaternary rocks), lehti - sheet - 2223 Alavus. Suomen geologinen kartta (Geological map of Finland) 1:100 000 .

—, 1984. Alavuden ja Kuortaneen kartta-alueiden kallioperä. Summary: Pre-Quaternary rocks of the Alavus and Kuortane map sheet areas. Suomen geologinen kartta $1: 100000$, lehdet 2223 ja 2224. (Explanation to the maps of Pre-Quaternary rocks, map sheets 2223 and 2224).

Weber, F. Harold, 1963. Geology and mineral resources of San Diego County, California. County report 3, 309 p.

Webster, Robert, 1962. Gems. Vol. 1. Butterworths \& co, London.

Manuscript received 1. February, 1985 